\title{
Habakkuk 2:5a: Denouncing 'wine' or 'wealth'? Contextual readings of the Masoretic text and 1QpHab
}

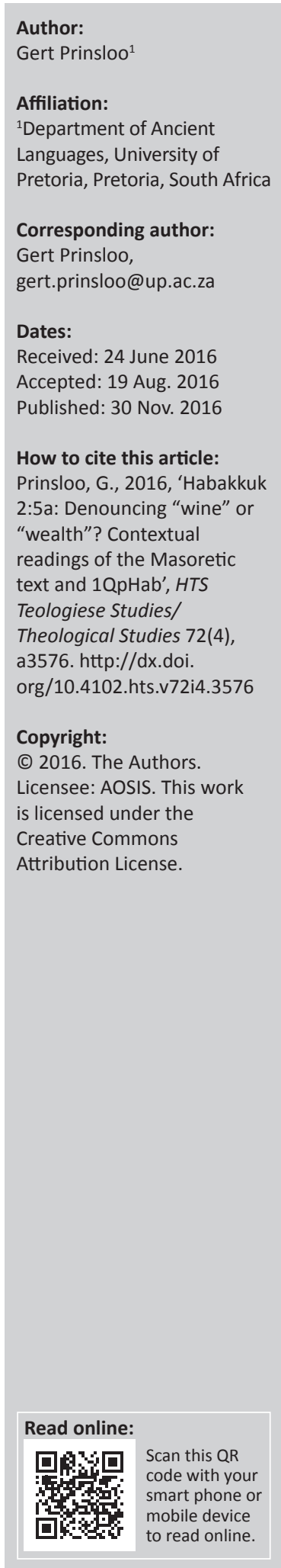

\begin{abstract}
Habakkuk 2:5 is a problematic text. The 'correctness' of the Masoretic text's passage 'moreover, the wine is treacherous, an arrogant person - he will not come to rest' has often been questioned. The discovery of the Pesher Habakkuk (1QpHab) in Cave 1 at Qumran gave impetus to this tendency. It contains a reading quite different from the Masoretic text. It reads 'moreover, wealth deceives an arrogant man, and he will not come to rest'. Many modern commentaries and translations assume that $1 \mathrm{QpHab}$ contains the 'correct' reading. This study argues that this assumption is based upon questionable text critical practice and pleads for a contextual interpretation of variant readings before rash decisions about the status of the Masoretic text can be made.
\end{abstract}

\section{Introduction}

Several interpretational problems confront readers in Habakkuk 2:5. ${ }^{1}$ What is the function of the

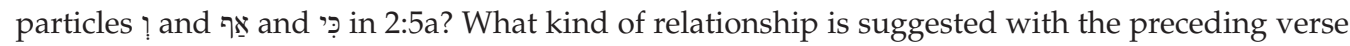
and with the following verses? What is the meaning of [the wine] in 2:5a and does the presence of the definite article have particular significance? What is the syntactic function of the participle

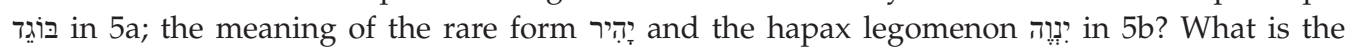
syntactic relationship between $5 \mathrm{ab}$ and 5cd? Especially under suspicion is the phrase in the Masoretic text (MT) of 2:5a. A reference to wine is absent in some of the ancient versions (Septuagint; Peshitta). Lothar Perlitt bluntly states that a reference to wine gibt hier kein Sinn (Perlitt 2004:67). ${ }^{2}$ Ever since the discovery of the Pesher Habakkuk in Cave 1 at Qumran (1QpHab), the version of 2:5a in the Pesher's quotation of 2:5-6 in 8.3-8 has been hailed as the perfect solution to the textual and interpretational difficulties posed by MT. Instead of MT's היין [the wine], 1QpHab reads הון, הון [wealth]. The syntactically awkward relationship

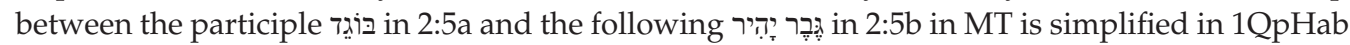
where an imperfect יבגוד as its logical object. Perlitt (2004:67) regards this as an empfehlenswerte Alternative to MT.

A classic criterion in the evaluation of textual variants is that the lectio difficilior often represents the preferred reading (see Brotzman 1994:128; Deist 1978:244-245; Tov 1992:302-305). ${ }^{3}$ The consummate ease with which 1QpHab's version of 2:5a is accepted is quite surprising. ${ }^{4}$ I question the assumption that $1 \mathrm{QpHab}$ contains the 'better' reading. ${ }^{5} \mathrm{My}$ thesis is that a balanced evaluation of variant readings in different textual witnesses is only possible if the literary and social context of each textual witness is taken into consideration. ${ }^{6}$ Confronted by the different readings of 2:5a in MT and 1QpHab, our first order of business is to ask the following questions: (1) Does ואף make sense in the context of MT? (2) Does the context of 1QpHab? 1.Roberts (1991:116) remarks, '[v]ery serious textual problems make the interpretation of Hab. 2:5a hazardous'.

2.Roberts (1991:113) remarks, "[o]ne can do nothing with MT's "wine is treacherous"'.

3.It is no absolute principle (Brooke 2013:3-4; Brotzman 1994:128; McCarter 1986:13), but its 'basic validity ... cannot be denied' (Tov 1992:303).

4.Van der Woude (1978:39) remarks, "[ $h$ ]et in de context nauwelijks aanvaarbare hayyayin, "de wijn", moet ongetwijfeld [my emphasis] met steun van 1 Q pHab (hwn) in hōn, "bezit, vermogen", gewijzigd worden'.

5.This study is not concerned with text-critical practice as such (see Brooke 2013:1-17). Sources for Hebrew Bible textual criticism attest to a variety of textual forms (Lim 2000:66). All variants cannot be ascribed to scribal errors (Barthélemy 2012:97-136). It 'is simply no longer appropriate to embark on the quest for the original form of the text, and especially no longer fitting to consider the MT as representing some form of Ur-text' (Brooke 2013:7-8). Textual diversity should not be 'reduced to a chosen, preferred reading' (Brooke 2013:17).

6.A list of variant readings for specific words and phrases in MT in 'critical' editions of the Hebrew Bible indicates that, according to the editors of the critical edition, variant readings exist in other textual witnesses. Such lists by definition disregard the context of MT and the alternative textual tradition. Ideally interpreters should evaluate variant readings in the context of all the respective textual traditions before deciding to emend texts. 
Failure to ask these fundamental questions leads to rash decisions about 'better' readings and disregards the possibility that different but equally valid versions of texts of Jewish origin might have existed at the dawn of the Common Era. ${ }^{7}$ This study is (1) a plea for contextual interpretations of two alternative textual traditions of Habakkuk 2:5a and (2) an argument for the retention of both readings in their respective contexts and against the practice of using one to 'correct' the other.

\section{Habakkuk 2:5a: Ancient textual witnesses and modern studies - a review}

In this section two issues are investigated:

- The delimitation of units in Habakkuk 2:1-8 as expressed by ancient scribal delimitation markers in various manuscript traditions (see Oesch 1979; Tov 2000:312-350):8 The purpose is to indicate how 2:5a is perceived in ancient scribal traditions to fit into its immediate context, especially in relation to $2: 4$ and $2: 6 .{ }^{9}$

- The text of Habakkuk 2:5a in various ancient textual witnesses: The purpose is to indicate that three textual traditions regarding 2:5a exist in ancient textual witnesses.

\section{Habakkuk 2:5a: Unit delimitation in ancient textual witnesses}

In a study of ancient scribal unit delimiters in Habakkuk I remarked: 'It is quite surprising that the most basic of exegetical exercises, namely the demarcation of both larger and smaller units, has not been adequately addressed' (Prinsloo 2009:198). ${ }^{10}$ Apart from some general remarks on the delimitation of units in Habakkuk 2 (Prinsloo 2009:215217), I have not undertaken a detailed study of the implications of unit delimitation for the interpretation of Habakkuk 2 yet. This section is a step in that direction with a very specific focus, namely the relationship between $2: 4-5$ and 2:5ff. It is important for the interpretation of Habakkuk 2. There has been considerable debate about the extent and content of the Habakkuk was instructed to write down (2:2b), a question directly related to the relationship

\footnotetext{
7.Available textual materials for the Second Temple period 'bountifully attest to a pluriformity - and as far as we can tell, a fully accepted pluriformity - in the text of pluriformity - and as far as we can
the Scriptures' (Ulrich 2000:86).

8.See Korpel (2000:1-50) for a discussion of the principles of unit delimitation. In a previous study I argued that

modern exegetes have at their disposal the very ancient system of spaces left open in (setumot) or at the end of lines (petuhot) which can aid them in making decisions about the structure of texts, at least as the structure was perceived by decisions about the structure of texts,
ancient scribes. (Prinsloo 2009:197).

9.The text-critical and interpretational problems of 2:4 deserve a comprehensive study of their own (see Andersen 2001:208-216 for an overview). Only the relationship between $2: 4$ and 5 will be touched upon here.

10. Initially I regarded Habakkuk as a dialogue between the prophet and YHWH (Prinsloo 1989:243). Later I demarcated two major units (1:1-2:20; 3:1-19), each introduced by a superscript $(1: 1 ; 3: 1)$ and questioned the book's 'dialogic structure (Prinsloo 1999:520-526). Research in the field of unit delimitation prompted me to reconsider my opinions. I argued that 1:2-17 is 'not a dialogue prompted me to reconsider my opinions. I argued that 1:2-17 is "not a dialogue between Yahweh and the prophet, but a single lament ... about the increase in violence and the disintegration of society at the end of the seventh century BC (Prinsloo 2004:637). With reference to Habakkuk 3 I argued that ' $[d]$ ata in ancien Hebrew manuscripts suggest that three major sections can be demarcated in Habakkuk 3, namely $3: 1-7,3: 8-13$ and $3: 14-19$ (Prinsloo 2013b:4) and that ancient unit delimiters 'transcend the neat borders between units demarcated on form critical grounds' (Prinsloo 2013b:7).
}

between 2:4 and 5. Some regard 2:1-4 as a unit (Deden 1953:263; Elliger 1956:41; Nowack 1903:283; Van Katwijk 1912:51; Prinsloo 1999:524-525)., ${ }^{11}$ others 2:1-5 (Deissler 1984:226; Rudolph 1975:216; Sellin 1930:399), ${ }^{12}$ still others 2:1-5b (Brownlee 1971:258-259; Prinsloo 1989:132), ${ }^{13}$ whereas some are of the opinion that 2:1-20 should be read as a single pericope (Van der Woude 1978:31). ${ }^{14}$

A key issue in this discussion is the interpretation of ואף כי in 2:5. The function of the combination of three conjunctive and/or subordinate particles without any obvious referent is controversial. For those who propose a close relationship between 2:4 ואף כי 5 [how much more and/or less ...] introduces an argument $a$ minori ad maius (Rudolph 1975:213; Van der Woude 1966:367-375, 1970:281-282). For others there is no logical a minori ad maius connection between 2:4 and 5 (Roberts 1991:116) and ואף כי functions as an 'emphatic connective' (Bratcher 1985:145) to be translated by something like 'yes, indeed ...' (Deissler 1984:226; Van Katwijk 1912:108; Van der Woude 1978:39).

Principles of unit delimitation can assist modern interpreters in making exegetical decisions. Addendum 1 contains a brief discussion of textual witnesses used in this study and their bibliographical information. The consulted Hebrew textual witnesses unanimously suggest a section break between 1:17 and 2:1 and again between 2:8 and $9 .{ }^{15}$ Witnesses are divided about the delimitation of units in 2:1-8. Some regard it as a single paragraph, whereas others have a division between 2:4 and $5 .{ }^{16} 1 \mathrm{QpHab}$ supports this division. It quotes Habakkuk $2: 4 a$ in $7: 14-15 ; 2: 4 b$ in $7: 17 ; 2: 5-6$ in $8: 3-8 ; 2: 7-8$ a in $8: 13-15$; $2: 8$ a again in $9: 3-4$ and $2: 2: 8 b$ in $9: 8$. The combination of $2: 5-6$ in the quote in 8:3-8 suggests a close relationship between the introduction to the woe oracles $(2: 5-6 \mathrm{~d})$ and the first oracle itself $(2: 6 \mathrm{e}-8)$. Data from the Hebrew manuscripts is summarised in Table 1.

Greek textual witnesses by and large support the delimitation traditions in Masoretic manuscripts. Greek manuscripts

TABLE 1: Paragraph markers in Hebrew manuscripts.

\begin{tabular}{lcccccc}
\hline Before & $\mathbf{M}^{\mathrm{C}}$ & $\mathbf{M}^{\mathrm{A}}$ & $\mathbf{M}^{\mathrm{L}}$ & $\mathbf{M}^{\mathrm{P}}$ & $\mathbf{M}^{\mathrm{R}}$ & BibR \\
\hline 2:1 & 0 & 0 & 0 & 0 & 0 & 0 \\
2:5 & 0 & 0 & -- & 0 & -- & -- \\
2:9 & 0 & $D$ & $D$ & $D$ & 0 & 0 \\
\hline
\end{tabular}

Source: See Addendum 1 for the full bibliographical particulars of the Hebrew manuscripts consulted

11. Habakkuk $2: 4$ contains the content of the with $2: 5-6 c \alpha$ as introduction to the woe oracles.

12. Habakkuk 2:4-5 contains the content of the with 2:6a-c $\alpha$ as introduction to the woe oracles.

13. Habakkuk 2:4-5b contains the content of the with 2:5c-6c 1 as introduction to the woe oracles.

14. He regards 2:4 as the content of the whereas 2:5-20 is a kind of 'commentary' by the prophet upon YHWH's revelation in 2:4.

15. Between 1:17 and 2:1 MurXII has a Petûhthâ, while $\mathrm{M}^{\mathrm{C}}, \mathrm{M}^{\mathrm{A}}, \mathrm{M}^{\mathrm{L}}, \mathrm{M}^{\mathrm{P}}, \mathrm{M}^{\mathrm{R}}$ and BibR have a $S^{e} t u ̂ m a \hat{a}$. The consulted witnesses agree that a section break occurs between 2:8

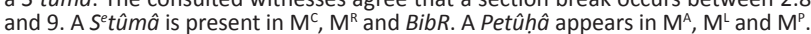
MurXII is too fragmentary to determine the presence or absence of a delimiter.

16. No division is apparent in $\mathrm{M}^{\mathrm{L}}, \mathrm{M}^{\mathrm{R}}$ and $B i b R$. It is supported by the Peshitta and the Vulgate. A S $S^{e}$ tumma appears between $2: 4$ and 5 in $\mathrm{M}^{\mathrm{C}}, \mathrm{M}^{\mathrm{A}}$ and $\mathrm{M}^{\mathrm{P}}$. MurXII is too fragmentary to determine the presence or absence of a delimiter. 
indicate in various ways that a new section begins with 2:1. ${ }^{17}$ Septuagint manuscripts demarcate 2:1 as a sub-unit, an indication that it was regarded as an introduction to 2:2-20.18 There is no uniform treatment of $2: 2-8$ in Septuagint manuscripts. Whereas $2: 2-8$ is subdivided into smaller units by some, ${ }^{19}$ no subdivisions are apparent in others. ${ }^{20}$

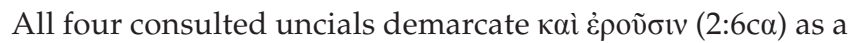
separate phrase. ${ }^{21}$ Thus, Greek manuscripts attest to the following: 2:1 is regarded as an introductory phrase in all manuscripts. As in some Hebrew manuscripts, Greek witnesses subdivide 2:2-8, regarding $2: 2-4$ as a unit and $2: 5-6 \mathrm{c} \alpha$ as an introduction to the series of woe oracles commencing in 2:6c $\beta-20 .{ }^{22}$ Other Greek witnesses support the second Hebrew tradition with no subdivision in $2: 2-8{ }^{23}$ The two traditions in the consulted textual witnesses are summarised in Table 2.

In the evaluation of these witnesses, another classic principle in Hebrew textual criticism should be kept in mind, namely that textual evidence should be weighed and not counted (see Deist 1978:243-244; Tov 1992:300-301). The division of 2:1-8 into two paragraphs is attested in the Pesher Habakkuk and in three Masoretic codices dating from before $1000 \mathrm{CE}$. This tradition cannot simply be discounted.

\section{The text of Habakkuk 2:5a In ancient textual witnesses}

When the text of 2:5a is compared in six ancient textual witnesses (see Addendum 2), different textual traditions are apparent. The basic tenet in all witnesses is clear. All denounce

TABLE 2: Demarcated paragraphs in Habakkuk 2:1-8.

\begin{tabular}{lll}
\hline Witness & Tradition 1: Single paragraph & Tradition 2: Two paragraphs \\
\hline Hebrew & $M^{L}, M^{R}, B i b R$ & $M^{C}, M^{A}, M^{p}, 1 Q p H a b$ \\
Greek & $G^{B}, G, G^{Q}$ & $G^{A}$ \\
Others & Peshitta, Vulgate & -- \\
\hline
\end{tabular}

Source: See Addendum 1 for the full bibliographical particulars of the manuscripts consulted.

17.The division is indicated: (1) In $\mathrm{G}^{\mathrm{A}}$ : high dot after 1:17; space left open in the line after 1:17; $2: 1$ commences with a large letter and ekthesis. (2) In $\mathrm{G}^{\mathrm{B}}$ : double dot after 1:17;
line is left open; $2: 1$ commences with ekthesis. (3) In $\mathrm{G}^{\mathrm{Q}}$ : high dot between 1:17 and $2: 1 ; 2: 1$ commences with a large letter. (4) In $G^{5}:$ a high dot between $1: 17$ and $2: 1$ 8 HevXIIgr also supports the division by leaving the line open after 1:17. The manuscript is too fragmentary to determine the presence or absence of unit delimiters in 2:1-8.

18.(1) In $G^{A}$ : line left open after $2: 1 ; 2: 2$ commences with ekthesis and a large letter paragraphos in the left hand margin in the last line of $2: 1$. (2) In $\mathrm{G}^{\mathrm{B}}$ : double dot after 2:1; space left open in the line before $2: 2$ commences. (3) In $G^{\text {s: }}$ double dot after 2:1; 2:2 commences with ekthesis. (4) In $\mathrm{G}^{\mathrm{a}}$ : high dot between $2: 1$ and 2:2.

19. In GA 2:2-8 is subdivided into four units: (1) 2:2-4: High dot between 2:4 and 2:5 $2: 5$ commences with ekthesis and large letter. (2) 5a-e: High dot after 2:5e and the $2: 5$ commences with ekthesis and large letter. (2) 5 a-e. High dot after $2: 5$ and the rest of the line is suggests that the break between 2:5e and 2.5 is not strong. (3) 2.5f-6ca: High do fter 2:6c $\alpha$; space left open in the line before $2: 6 c \beta$; first letter of the next line is

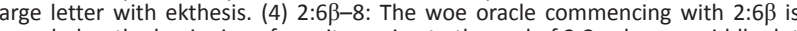
regarded as the beginning of a unit running to the end of $2: 8$, where a middle do appears between $2: 8$ and 9 and $2: 9$ commences with a large letter with ekthesis.

20. $G^{B}$ and $G^{S}$ have no subdivision in 2:2-8. $\ln G^{B}$ a double dot separates $2: 8$ and 2:9 and 2:9 commences with ekthesis. No delimiters occur in $\mathrm{G}^{\mathrm{S}}$ after $2: 8 . \mathrm{G}^{\mathrm{a}}$ regards $2: 2-6 \mathrm{~b}$ as a unit. Ekthesis and the presence of a paragraphos suggest that a new unit commences with 2:6c. A high dot between 2:8 and 2:9 and a paragraphos in the left hand margin indicate that $2: 6 c-8$ should be regarded as a unit.

21.It is preceded and followed by dots in all four manuscripts, suggesting that the Greek tradition regarded the phrase as an introductory formula to the following series of woe oracles.

22.See $M^{\mathrm{C}}, \mathrm{M}^{\mathrm{A}}, \mathrm{M}^{\mathrm{P}}, 1 \mathrm{QpHab}$.

23.See $M^{L}, M^{R}$, BibR, Peshitta, Vulgate. 'an arrogant person' whose insatiable appetite for violence is likened to Sheol [death] and finds expression in his obsession to gather to himself all the nations or peoples.

With regard to 2:5a, however, three textual traditions are apparent. The first refers to the treacherous nature of wine, which has exactly the effect described in the rest of the verse - those who become addicted to it always crave more. It is reflected in MT, the Targum and the Vulgate and is followed in many modern translations. ${ }^{24}$ The second does not refer to wine, but contains a number of synonyms for

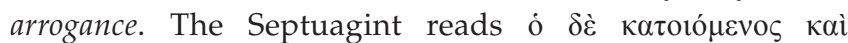

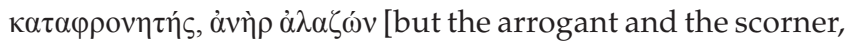
the boastful man] and the Peshitta [the arrogant and greedy man]. It is followed in a number of modern translations. ${ }^{25}$ The third tradition is present only in 1QpHab, where MT's הייו is replaced by the הון [wealth]. ${ }^{26}$ This reading is popular in so-called dynamicequivalent translations. ${ }^{27}$

Unit delimitation thus suggests that consideration should be given to the scribal tradition demarcating a section break between 2:4 and 2:5. It implies that 2:5 should be interpreted in light of the following verses, and 2:5-20 then in conjunction with 2:1-4. A comparative reading of various textual witnesses suggests the existence of three traditions regarding 2:5a. Is wine, arrogance or wealth denounced in 2:5a? In this study I will focus on two of the three textual traditions and ask whether 'wine' or 'wealth' is denounced in 2:5a.

\section{Towards contextual readings of Habakkuk 2:5a in MT and 1QpHab}

Table 3 contains the text of Habakkuk 2:5-6 in MT and its quotation and interpretation in 1QpHab 8.3-13. Words marked in grey indicate differences between MT and 1QpHab. Words encircled indicate links between the quotation of 2:5 in 1QpHab and its interpretation.

I return to my main thesis, namely that a meaningful and balanced evaluation of variant readings in different textual witnesses is only possible if the variants are evaluated taking the literary and social context of each textual witness into consideration. Two questions should be asked: (1) Does

24.See Luther Bibel (1545); King James Version (1611); Statenvertaling (1637); Revised Standard Version (1952); New International Version (1984).

25.See Nederlandse Bijbelgenootschap (1951); Revidierte Lutherbibel (1984); New Living Translation (1996).

26. According to Brownlee (1979:132) the Septuagint and Peshitta are based upon a Hebrew original reading הָּ [the arrogant]. He relates the noun to the single instance where the root הון occurs as a verb in the Hebrew Bible, namely as a Hiph'îl Imperfect verb in Deuteronomy 1:41 (ות ותינוּ [and they regarded it as easy]). The text implies that the Israelites were presumptuous and regarded the conquest of Canaan as easy to execute. Barthélemy (1992:844) and Gelston (2010:118-119) accept this proposal and it became the 'preferred' reading recommended in the critical apparatus of Biblia Hebraica Quinta. I am not convinced that this (thecal apparatus of Biblia Hebraica Quinta. I am not convinced that this (theoretical) noun should be preferred to nouns that are perfectly legible in the context of MT (הin ) and 1QpHab (ה) I would rather regard the rendering of Habakkuk 2:5 in the Septuagint and Peshitta as a paraphrase of the intent of MT's
metaphorical use of

27.See Today's English Version (1976); Nuwe Afrikaanse Vertaling (1983); New Revised Standard Version (1989) 


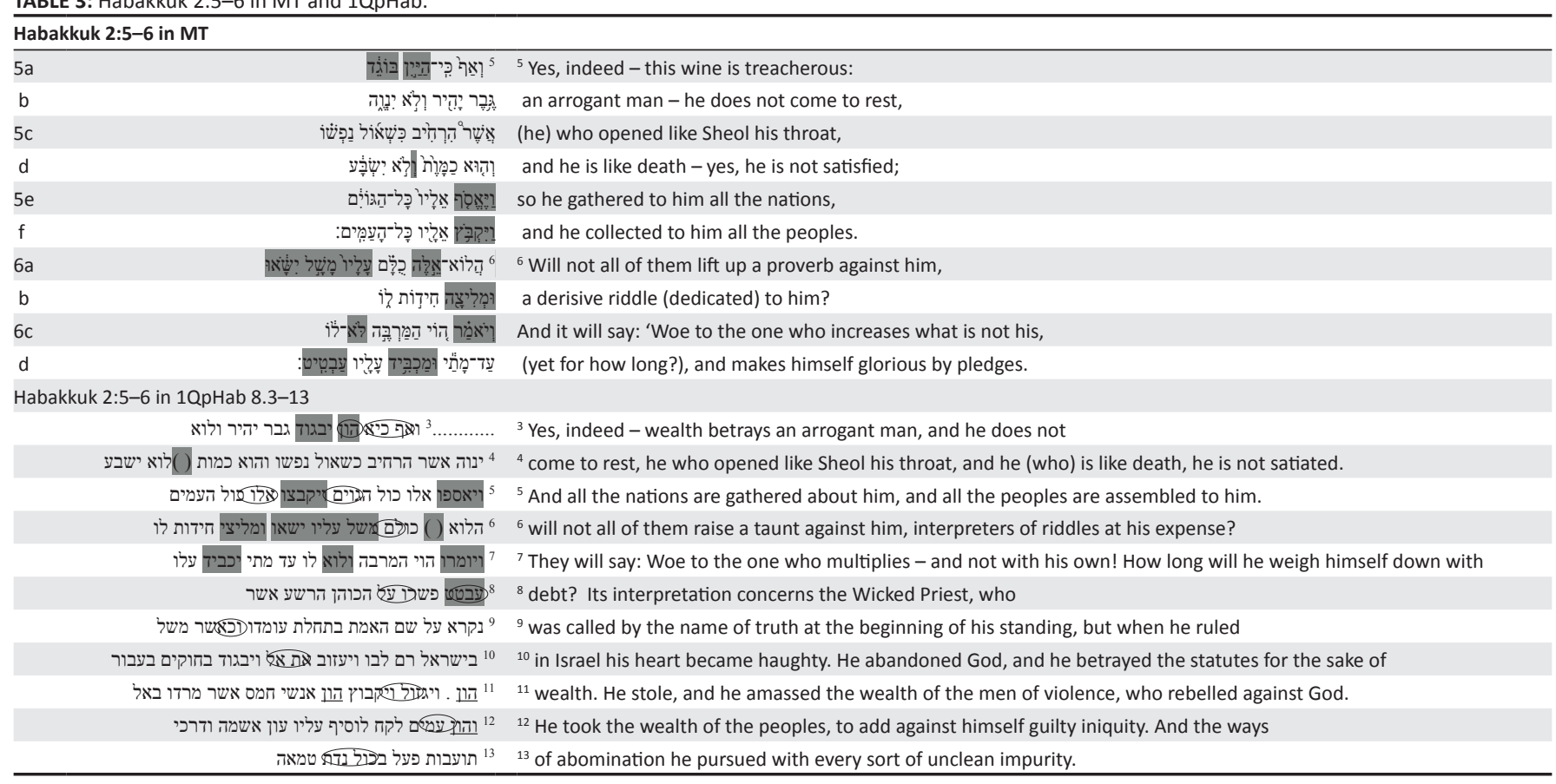

Source: Author's own work

[wealth] make sense in the context of 1QpHab? (2) Does היין [the wine] make sense in the context of MT?

\section{Reading הוץ [wealth] in the context of 1QpHab}

Does הון [wealth] make sense in the context of 1QpHab? Three issues should be kept in mind in a contextual interpretation of 1QpHab 8:3-13.

The first is the Pesher's socio-historical context. The scroll dates from the latter half of the first century $\mathrm{BCE},{ }^{28}$ but was probably first written in the time of Alexander Jannaeus (103-176 BCE) (Fabry 2003:252). It should be read against the background of the conflicts between successive imperial powers of the time (the Persians, Greeks and Romans) and their influence upon the Jewish minority in and around Jerusalem..$^{29}$ It should especially be read in the light of the second and first century BCE's emerging and often conflicting Judaism(s). ${ }^{30}$ A core belief 'of Second Temple Judaism was to view the totality of the Jewish people as an organic whole, almost like a single body that was chosen by God' At the same time 'individual religious communities ... proliferated during this period', all adhering to 'this overarching view of Israel's sanctity', but

28.According to Horgan $(2002: 157)$ the script of both identifiable handwritings in the scroll $(1: 1-12: 13 ; 12: 13-13: 4)$ is Herodian. The copying of the scroll 'can probably be placed in the second half of the first century BCE.'

29.For the history of the period, cf. Jagersma (1985); Kaiser (1998:447-486). In his history of Hasmonean high priesthood Vanderkam (2004:240-393) gives valuable information regarding the period.

30.Grabbe (2010) identifies four 'currents' in emerging Judaism: a priestly and scribal current or 'textual Judaism' (2010:40-65); political and 'messianic' currents or 'revolutionary Judaism' (2010:66-86); an apocalyptic current or 'eschatological Judaism' (2010:87-108); and a gnostic current or 'inverted Judaism' (2010:109127). Cf. also Sanders (2000:1-43). He remarks:

The Qumran community had much in common with other Jews of the same place and time. It was, however, a very radical group, and in numerous ways it was distinctive, so distinctive that it separated itself from other Palestinian Jews. (2000:32) 'each group established its own ways to live a life of sanctity and saw itself as verus Israel' (Flusser 2009:8). Some groups 'placed their hopes in the institutions and leaders of their day, whether the High Priests, the Ptolemies, or the Maccabees' and 'had little interest in messianism', while '[a]pocalyptic groups developed the idea of a transcendent savior figure, either as an alternative or as a complement to earthly messianism'. At Qumran 'we find a group with a strong and developed interest in messianism' (Collins 1987:106).

The second is the nature of the Qumran community. Sometime 'before 150 BCE centuries of tension within the many priestly groups in the Jerusalem Temple came to a climax' and 'the Righteous Teacher led a group out of the Temple and Jerusalem and southeastward into the wilderness' (Charlesworth 2002:37) and established the so-called Qumran community:

[The] Qumran phenomenon derives from larger and earlier sectarian apocalyptic movements. It is likely that the origins of the Qumran Community are to be found 'within the Essene movement' which antedates Qumran, but that the settlement at Qumran dates towards the latter half of the 2nd century BCE. $(2002: 55-56)^{31}$

Much has been written about the community's mode(s) of self-identification and their 'sectarian' identity (Berg 2011:333-349; Jokiranta 2013; Newsom 2004) ${ }^{32}$ :

31.Cf. García Martinez (2007:3-29, 31-52) for a discussion on the origins and nature of the Qumran community. I concur with the basic tenets of the 'Groningen Hypothesis' which places 'the origins of the Essene movement in the Palestinian Hypothesis which places the origins of the Essene movement in the Palestinian apocalyptic tradition of the late 3rd and early 2 nd c. BCE, helps us to understand how and why within this Essene movement the influence of the Teacher of Righteousness gave rise to a fringe group and makes it clear how after opposing the Essene Community and retired to the desert' (García Martínez 2007:29).

32.For the history of the community, cf. García Martínez (2007:67-89). 
[They] called themselves 'the Poor Ones', 'the Good Ones', 'the Sons of Aaron', 'the Sons of Light', 'the Sons of Truth', 'the Sons of Dawn', 'the Sons of Zadok', 'the Sons of Righteousness', 'the Righteous Ones', 'the Perfect Ones', 'the Perfect in the Way', 'the Holy Ones', and 'the Most Holy Ones'. (Charlesworth 2002:73)

\section{The Qumran community:}

... can best be described as a group of Jews possessed by an ardent messianic vision ... By extrapolating biblical texts, they had worked out the exact date of the onset of the ideal 'Age to Come', and held themselves in readiness to welcome its harbringers, the 'Anointed', who would usher it in. (Talmon 1987:115)

The third is the nature of the pesher genre. Pesher [פשר] 'is a term ... largely distinctive of the Qumran sectarian literature' (Brooke 2013:101). It introduces 'a revealed interpretation ... of an earlier revelation' (Silberman 1961:326), indicates 'the meaning of a biblical word, phrase or verse' (Lim 2000:59) and 'introduces the specific point of reference from which the entire verse is to be understood' (Silberman 1961:328). The pesharim 'are hermeneutically focused. They are biblical commentaries in the sense of fulfilment hermeneutics' (Charlesworth 2002:5-6). Pesher interpretation 'is pneumatic, eschatological, and "fulfilment interpretation"; it is also self-serving and idiosyncratic' (2002:68). The pesherist read the biblical text in the light of his community's interests and circumstances, as if 'the ancient men of wisdom, especially the prophets, focused their thoughts on the latter days' and as if the 'Qumranites ... were living in the latter days of time and history' (Charlesworth 2002:70). ${ }^{33}$ The 'Habakkuk Pesher and, indeed, all Pesher material are related on one side to Daniel and on the other to a body of midrashim whose structure is parallel to and perhaps derived from the form found in Daniel and developed in the Qumran pesharim' (see Instone Brewer 1992:187-198; Silberman 1961:326)..$^{34}$

In 1QpHab 8:3-13 both the biblical lemma (8:3-8) and its interpretation and application (8:8-13) should be read against this background. ${ }^{35}$ The interpretation 'is not merely juxtaposed to the lemma with but superficial relation to it. Rather does it grow out of the lemma, using literary devices to establish the connection' (Silberman 1961:334). The term הון [wealth] is key in 8:3-13. It occurs four times, once in the lemma (8:3) and three times in the application (8:11-12). The term הון occurs another five times in 1QpHab $(1: 8 ; 6: 1 ; 9: 5,6$; 12:10). The Pesher 'mentions wealth more extensively than any of the other exegetical works' (Murray 2002:235) and always uses the term in the sense of illegitimately taking the 33.On apocalypticism and the Dead Sea Scrolls, see García Martínez (2007:195-226).

34.For Brownlee (1951:76) and Slomovic (1969-71:5) the exegesis in 1QpHab is essentially midrashic in character'. Elliger (1953:156-157) regards the dream interpretations in Daniel 2, 4, 5 and 7, also introduced by 7 שפ, as the background for pesher exegesis. For Brooke (1985:4) pesher exegesis stands fully in the tradition of 'early Jewish exegesis and especially that exegesis' technical
methodology'.

35.See Brownlee (1979:131-144) for a detailed exegesis of the passage. 10pHab $8: 3-13$ is the first paragraph in an extended passage $(8: 3-12: 10)$ where Habakkuk 2:5-17 is applied to the Wicked Priest and his disciples (Potgieter-Annandale 1999:77). possessions of others. The Qumran community 'displayed a distinct antipathy towards wealth and they regarded it as the result of violence, pillage and oppression' (PotgieterAnnandale 1999:81). In 1:8 and 6:1 the Romans are accused of seizing the wealth of others in order to increase their own wealth. Especially the so-called Wicked Priest is accused of committing this atrocity. In 8:3 Habakkuk 2:5 is quoted as 'wealth betrays a haughty man ...' It is applied to the Wicked Priest, who is accused of betraying God's statutes for the sake of wealth (8:11) and of amassing the wealth of men (8:11) and taking the wealth of peoples (8:12). In 12:10 he is accused of stealing the wealth of the poor ones. The last priests of Jerusalem are also accused of amassing wealth and profit (9:5) and warn that it will be given into the hands of the army of the Kittim (9:6).

הון occurs about 140 times in the Dead Sea 'sectarian' texts and can be regarded as a key concept for the Qumran community. ${ }^{37}$ The Damascus Document $(14 x)^{38}$ stipulates:

that wealth be used to build up the community rather than to elevate the individual ... Wealth is a boundary marker for the community as well as a proper domain for its scrutiny and judgement. (Damascus Document)

The community disdains the arrogance and viciousness associated with wealth ... and give economic witness to the eschatological justice for which they hope' (Murray 2002:102). The Rule of the Community $(23 x)^{39}$ shares with the Damascus Document 'an intense interest in wealth'. Whereas the Damascus Document focuses upon 'socio-economic critique', in the Rule:

... priority is given to the alternative ideal community ... organised around a renewed covenant. This new covenant, in turn, reorients the agricultural-sacrificial enterprise away from the urban sanctuary and towards the wilderness congregation committed more radically than others to the statutes of Deuteronomy. (Murray 2002:162)

4QInstruction and other wisdom texts $(26 x)^{40}$ presume 'an audience that regularly finds itself in difficult economic circumstances to which the pooling of resources, charity and in the last resort loans appear to be the only avenues of recourse' (Murray 2002:209). In the Pesharim (10x) ${ }^{41}$ there is 'the association of arrogance and wickedness with wealth, the self-identification of the community as the poor and the meek' and 'the assertion that God will bless these poor ones by feeding them' (Murray 2002:235).

\footnotetext{
36.An exact count depends upon textual reconstructions. I did not take parallel texts (e.g. 1QS V.1-4 // 4Q258 I.2-3) into consideration but did a simple count of all occurrences of The statistics simply illustrate that it is a keyword in the Dead Sea Scrolls.

37.The 'despising of personal wealth is characteristic of the Essenes and of this sect' (Brownlee 1951:67 n. 39).

38.CD 4:17; 6:15, 16; 8:5, 7; 9:22; 10:18; 11:15; 12:7; 13:11; 19:17, 19; $20: 7$.

39.10 S $1: 12,13 ; 3: 2 ; 5: 2,3,14,16,20 ; 6: 17,19,22,25 ; 7: 6,25$ (2x); 8:23; 9:7, 8, 22; $10: 19 ; 11: 2$.

40.4Q416 (Instruction ${ }^{b}$ ): 5x; 40417 (Instructionc): 3x; 40418 (Instruction ${ }^{d}$ ): 11x $4 Q 420$ (Ways of Righteousness ${ }^{2}$ ): 1x; 4Q423 (Instruction ${ }^{\mathrm{B}}$ ): 2x; 4Q424 (Sapiential Text): $4 \mathrm{x}$.

41.10pHab 1:8; 6:1; 8:3, 11 (2x), 12; 9:5, 6; 12:10; 4Q169 (Pesher Nahum) f3_4i:11.
} 
Slomovic (1969-71:15) argues that in 8:3-13 the general idea of the pesher is apparent. The Wicked Priest, after a period of enjoying a reputation for truth, grew arrogant and betrayed God and his precepts for the sake of wealth. Wealth was the underlying cause for his betrayal' (my emphasis). ${ }^{42}$ Departing from the reading ואף כַיא הון (8:3) the pesherist was able to apply the biblical phrase to in 8:8. ${ }^{43}$ For Brownlee (1951:67) the 'explication of the passage grows out of its distinctive readings.' He identifies three distinctive readings of the biblical text in היין הון [wealth] is read instead of MTher: Firstly, [the wine], allowing the pesherist to make deceptive wealth the key term that 'drives several sentences in the interpretation' (VanderKam 2011:356). Secondly, for the pesherist MT's מָָָׁ [proverb] (2:6; see 1QpHab 8:6) implies something cryptic (Brownlee 1951:67), hence it is read in the application as משל [to rule] in the phrase 'but when he ruled in Israel his heart became haughty' (8:9-10). ${ }^{44}$ Thirdly, the final word in MT 2:6, עִבְטִיט [pledge], is written defectively in 1QpHab 8:8, thus עבטט, yllowing the pesherist to read it as two words, עָב טָט [thickness of mud] and apply it as נדת טמאה [unclean impurity] (see Brownlee 1951:67, 1979:142). ${ }^{45}$ Hence the Wicked Priest, who once 'was called by the name of truth' (8:9) became laden בכול נדת טמאה 'with every kind of unclean impurity' (VanderKam 2011:358).

The accumulated evidence indicate that ואף כיא הון יבגוד גבר יהיר in 1QpHab 8:3 is an acceptable and explainable reading in the context of the Qumran community and its literature.

\section{Reading היין [the wine] in the context of MT}

Does היין [the wine] make sense in the context of MT? Three issues should be kept in mind in a contextual interpretation of Habakkuk 2:5-6.

The first is the text's socio-historical context. At least for Habakkuk 1-2, readers have to transpose themselves about 400 years earlier than the events suggested in the Pesher Habakkuk. The text can be read against the background of the Babylonian exile (Prinsloo 2013a:132-154). Habakkuk displays a 'curious reluctance to identify the wicked', yet 'there are hints that the Babylonians are the object of the scorn, the nation on whom imminent doom is pronounced'

42.The identity of the Wicked Priest is a contentious issue (see García Martínez 2007:53-66; VanderKam 2011:350-367). García Martínez allows for successive Hasmonean high priests/rulers to be called 'the Wicked Priest' and regards Judas Maccabeus, one of the leaders of the Maccabean revolt (167-160 BCE) as the likely candidate in 1QpHab 8:3-13 (García Martínez 2007:66). Vanderkam (2011:367) regards Jonathan, a brother of Judas Maccabeus who Vanderkam (2011:367) regards Jonathan, a brother of Judas Maccabeus who
was high priest in 152-142 BCE, as the most likely candidate. For Brownlee
(1982:18-26), John Hyrcanus, who was high priest in 134-104 BCE, is the likely candidate.

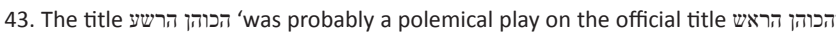
therefore it seems 'likely that the Wicked Priest was a high priest' (VanderKam 2011:352). According to Slomovic (1969-71:15) the pesherist applied the midrashic exegetical principle al tiqrei 'to change the masoretic הון to הייו'. Brooke (1985:333 n. 56) acknowledges the possibility 'but it could also be a simple textual variant belonging to the interpreter's text'. Through hillûf [anagram] the pesherist adapted (Brooke 1985:289).

44. גבר יהיר 2:5 'an arrogant man' (Brownlee 1979:138)

45 .
(Prinsloo 2013a:152). I inferred this from the 'many parallels between Habakuk 2 and oracles of doom in Isaiah directed against the Babylonians (cf. Isa 13-14; 21:1-10)' (Prinsloo 2013a:152). With reference to Habakkuk 3 I postulated that the:

... reference to 'the poor' (3:14) ... points to the poet of Habakkuk 3 being a member of a specific social group in the late Persian and/or early Hellenistic period who regarded themselves as the true Israel and as the actual recipients of YHWH's salvific intervention in and promises to his people. The poet appropriates YHWH's promise to the prophet Habakkuk at the time of the Chaldean onslaught on and devastation of Jerusalem to his own predicament as a marginalised 'poor' in a wicked and hostile environment. (Prinsloo 2013b:7)

The reference to היין 2:5 should be interpreted against the background of imperial powers' domination of the people of Judah/Yehud during the Babylonian exile and Persian/early Hellenistic rule.

Secondly, readers sensitive to intertextual allusions in the Hebrew Bible will recognise a number of ואף כי היין בוגד intertextual contexts illuminating the phrase in 2:5a. In wisdom literature the delusionary influence of היין [the wine] is a well-known motif (see Proverbs 23:29-35). Proverbs 20:1 is reminiscent of Habakkuk 2:5a's :היין בוגד:

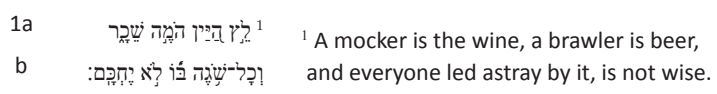

Wine is used as metaphor for YHWH's wrath. In Psalm 75:9 'the wicked of the earth' are condemned:

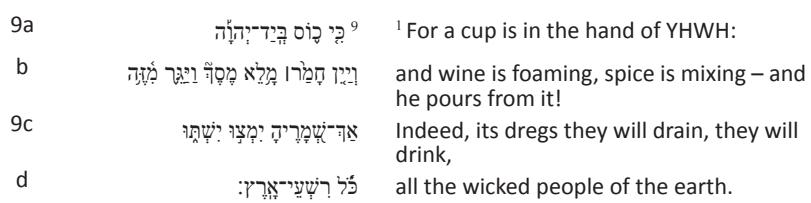

In prophetic literature YHWH's wrath is directed at Israel's enemies in general, and at one enemy in particular - the Babylonians. Jeremiah 25:15-38 is a pronouncement of universal judgement directed at 'Jerusalem and the towns of Judah, its kings and officials' (Jer 25:18) and all surrounding kingdoms (Jer 25:19-26). The prophet is instructed (Jer 25:15-16):

\begin{tabular}{|c|c|c|}
\hline $15 a$ & 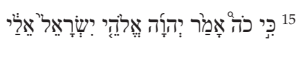 & $\begin{array}{l}{ }^{15} \text { For thus said YHWH the God of } \\
\text { Israel to me: }\end{array}$ \\
\hline$b$ & 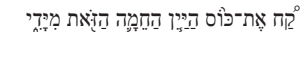 & $\begin{array}{l}\text { Take this cup of fuming wine from } \\
\text { my hand }\end{array}$ \\
\hline $15 c$ & 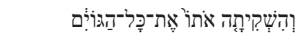 & and let all the nations drink it, \\
\hline$d$ & 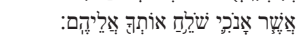 & those to whom I am sending you. \\
\hline $16 a$ & 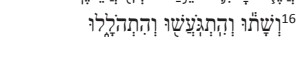 & $\begin{array}{l}{ }^{16} \text { They will drink, and they will } \\
\text { stagger, and they will go mad }\end{array}$ \\
\hline$b$ & 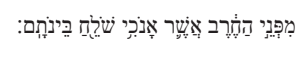 & $\begin{array}{l}\text { because of the sword that I will } \\
\text { send among them. }\end{array}$ \\
\hline
\end{tabular}

The prophet obeys and hands the cup to all nations (Jer 25:17-26). 
Jeremiah 51:1-58 is a pronouncement of Babylon's complete destruction. 'Wine' serves as metaphor for Babylon's violence (51:7-8):

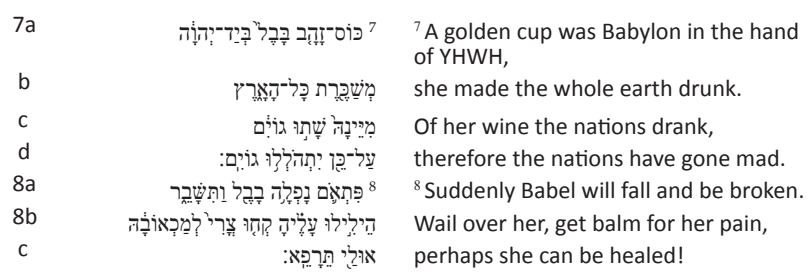

A similar picture emerges in Isaiah 51:17-23. The exiles are comforted (51:17):

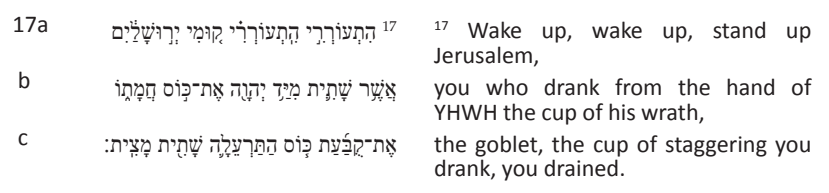

A complete reversal of fortunes is about to occur (51:21-23a):

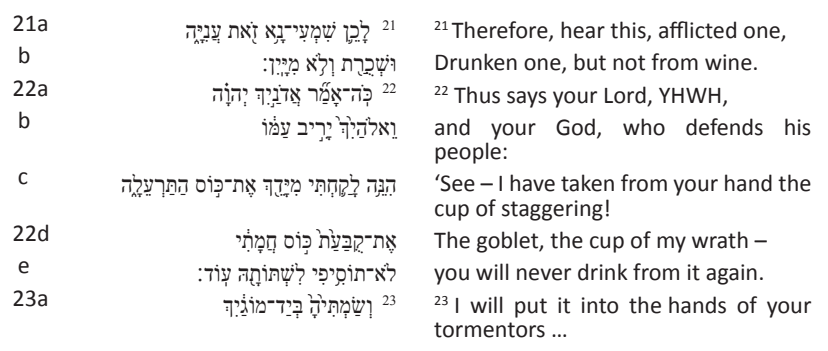

In Jeremiah 51:1-58 and Isaiah 51:17-23 'wine' is a metaphor for the Babylonians' violence against the people of Judah. The cup of wrath they handed to the Judeans will become the cup of wrath in the hand of YHWH and the Babylonians will now be forced to drink it. Daniel 5:1-31, a tale about the final destruction of the Babylonian Empire, repeatedly refers to 'the wine' drank at King Belshazzar's banquet from 'the gold goblets' taken by Nebuchadnezzar from 'the temple of God in Jerusalem' (see 5:1-4, 23). This action is interpreted by Daniel as a sure sign of Babylonian hubris (5:18-24) and it is the direct cause of the great empire's fall (Kaiser 1992:172).

The intertexts teach a general principle: היין [the wine] is deceptive or treacherous and not to be trusted (see לייו הי וn Prov 20:1). ${ }^{46}$ When it is used metaphorically for YHWH's wrath and/or a foreign power's violence, a Motivkonstellation is created that might be called 'drinking the cup of wrath from YHWH's hand'. ${ }^{47}$ It conveys a simple principle. The violence committed against others by imperial powers (metaphorically described as a cup filled with fuming wine) will turn against them. YHWH will force these powers to

\footnotetext{
46.Floyd (2000:113) remarks:

[a] taste for wine, when overindulged, can give a man such delusions of grandeur that he is bound to fall; and a taste for conquest, when overextended to cosmic proportions, can likewise predispose a conqueror to make fatal mistakes.

47. For the term, see Berges (2000:153).
}

drink the cup of wrath themselves. The constellation consists of six motifs: a drinking vessel - hand (of YHWH) fermented beverage - recipient(s) of the beverage consuming the beverage - effect.

Thirdly, principles of unit delimitation suggest that a section break between Habakkuk 2:4 and 5 should seriously be considered. If $2: 5$ is interpreted in the light of 2:5-20, intratextual links in the pericope indicate that the reference to in 2:5a is not 'hardly acceptable' (Van der Woude 1978:39) or 'senseless' (Perlitt 2004:67). On the contrary, the general intent of the text is clear:

Like delusory wine, the arrogant man will not reach his destination. These Chaldean kings will no longer continue with their pillage and their voracious gathering of nations into their realm ... At a certain moment in time the nations they have plundered will get the opportunity to scoff at the Chaldeans. (Potgieter-Annandale 1999:79)

If 2:5 is read in this context, the presence of the Motivkonstellation referred to above becomes apparent (see 2:5, 15-16). Table 4 summarises its manifestation in different contexts.

Read in this light the presence of היין [the wine] in 2:5a becomes perfectly legible. It refers to the arrogance of the wicked Babylonians, prompting them to gather more (2:6-8), secure more (2:9-11), build more (2:12-14), lust more (2:15-17) and in the end commit the ultimate folly of relying solely upon himself $(2: 18-19)$ in the presence of YHWH, who is in his holy palace and before whom all the Earth should hush (2:20). Their lust for 'wine' borders on the absurd and has become an insatiable obsession (2:5). Ironically, by committing the atrocities described in the woe oracles, the perpetrator of violent acts satiated himself with shame (2:16) and his downfall is inevitable.

The accumulated evidence indicate that the reading in MT 2:5a is an acceptable and explainable reading in the context of $\mathrm{MT}$.

\section{Conclusion}

In this study I expressed my surprise at the way Habakkuk 2:5 is dealt with in many commentaries and modern translations. There is a marked difference between MT's ואף כי היין בוגד and 1QpHab's ואף כיא הון יבגוד גבר יהיר. I argued that both readings should be evaluated in their respective contexts before rash decisions are made about the 'preferred' reading. I asked two basic questions: Does wealth make sense in the context of 1QpHab? My answer was in the affirmative, but it would be negative if the reading were transposed to the context of MT. Does wine make sense in the context of MT? Again my answer was in the affirmative, but it would be negative if the reading were transposed to the context of 1QpHab. In essence this study was a plea for contextual interpretations of two alternative textual traditions of Habakkuk 2:5a. 
TABLE 4: Drinking the cup of wrath from YHWH's hand.

\begin{tabular}{|c|c|c|c|c|c|c|c|}
\hline Motif & Ps. 75:9 & Jer. 25:15-15 & Jer. $51: 7-8$ & Is. 51:17 & Is. $51: 21-23$ & Hab. 2:5 & Hab. 2:15-16 \\
\hline Drinking vessel & כוס & כוס & כוס & קבעת כוס & קבעת כוס & & כוס \\
\hline Hand (of YHWH) & ביד יהוה & 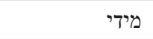 & ביד יהוה & מיד יהוה & ביד־מוגיך מידך & & ימין יהוה \\
\hline Fermented beverage & יין חמר & היין החמה & מיינה & המתו & חמתי מיין לא & היין - - - & חמתך - - - = \\
\hline Recipient(s) & כל רשעי־ארץ & כל־גוים & גוים כל־הארץ & & & כל־הגוים כל־העמים & רעהו \\
\hline Consume beverage & שתה מצה & שקה שתה & שתה & שתה מצה & שתה & & שקה שתה \\
\hline Effect & & הלל געש & שכר הלל & רעל & רעל שכר & ישבע לא & ערל שבעת שכר \\
\hline
\end{tabular}

Source: Author's own work.

\section{Acknowledgements \\ Competing interests}

The author declares that he has no financial or personal relationships that may have inappropriately influenced him in writing this article.

\section{References}

Andersen, F.I., 2001, Habakkuk, Doubleday, New York. (Anchor Bible, 15).

Barthélemy, D., 1992, Critique Textuaelle de l'Ancien Testament. Tome 3: Ezéchiel, Daniel et les 12 Prophètes, Vandenhoeck \& Ruprecht, Göttingen. (Orbis Biblicus et Orientalis, 50/3).

Barthélemy, D., 2012, Studies in the text of the Old Testament: An introduction to the Hebrew Old Testament text project, transl. S. Pisano et al., Eisenbrauns, Winona Lake, IN. (Textual Criticism and the Translator, 3).

Berg, S., 2011, 'Religious epistemology and the history of the Dead Sea Scrolls', in D.C. Harlow et al. (eds.), The "'other" in Second Temple Judaism: Essays in honor of John J. Collins, pp. 333-349, Eerdmans, Grand Rapids, MI.

Berges, U., 2000, 'Die Knechte im Psalter. Ein Beitrag zu seiner Kompositionsgeschichte', Biblica 81, 153-178.

Bratcher, D.R., 1985, The theological message of Habakkuk: A literary-rhetorical analysis, University Microfilms, Ann Arbor, MI.

Brooke, G.J., 1985, Exegesis at Qumran: 4QFlorilegium in its Jewish context, JSOT Press, Sheffield. (Journal for the Study of the Old Testament Supplement Series, 29).

Brooke, G.J., 2013, Reading the Dead Sea Scrolls: Essays in method, Society of Biblical Literature, Atlanta, GA. (Society of Biblical Literature: Early Judaism and Its Literature, 39).

Brotzman, E.R., 1994, Old Testament textual criticism: A practical introduction, Baker Grand Rapids, MI.

Brownlee, W.H., 1951, 'Biblical interpretation among the sectaries of the Dead Sea Scrolls', Biblical Archaeologist 14, 54-76. http://dx.doi.org/10.2307/3209322

Brownlee, W.H., 1971, 'The Composition of Habakkuk', in A. Caquot et al. (eds.), Hommages a André Dupont Sommer, pp. 255-275, Adrien-Maisonneuve, Paris. (Libraire D'Amerique et D'Orient).

Brownlee, W.H., 1979, The Midrash Pesher of Habakkuk, Scholars Press, Missoula, MT. (Society of Biblical Literature Monograph Series, 24).

Brownlee, W.H., 1982, 'The Wicked Priest, the Man of Lies, and the Righteous Teacher - The problem of identity', Jewish Quarterly Review 73, 1-37. http://dx.doi. org/10.2307/1454458

Charlesworth, J.H., 2002, The Pesharim and Qumran history: Chaos or consensus?, Eerdmans, Grand Rapids, MI.

Collins, J.J., 1987, 'Messianism in the Maccabean Period', in J.N. Neusner et al. (eds.) Judaisms and their Messiahs at the turn of the Christian Era, pp. 97-109, Cambridge University Press, Cambridge.

Deden, D., 1953, De kleine Propheten, J.J. Romen, Roermond. (Boeken van het Oude Testament, 12).

Deissler, A., 1984, Zwölf Propheten II. Obadia, Jona, Micha Nahum, Habakuk, Würzburg, Echter Verlag. (Neue Echter Bibel, 8).

Deist, F.E., 1978, Towards the text of the Old Testament, D.R. Church Booksellers, Pretoria.

Elliger, K., 1953, Studien zum Habakuk-Kommentar vom Toten Meer, J.C.B. Mohr (Paul Siebeck), Tübingen. (Beiträge zur Historischen Theologie, 15).

Elliger, K., 1956, Das Buch der zwölf kleinen Propheten II: Die Propheten Nahum, Habakuk, Zephanja, Haggai, Zacharja, Maleachi, Vandenhoeck \& Ruprecht, Göttingen. (Das Alte Testament Deutsch, 25).

Fabry, H.-J., 2003, 'The reception of Nahum and Habakkuk in the Septuagint and Qumran', in S.M. Paul et al. (eds.), Emanuel: Studies in Hebrew Bible, Septuagint and Dead Sea Scrolls in honor of Emanuel Tov, pp. 241-256, Brill, Leiden. (Supplements to Vetus Testamentum, 94).

Floyd, M.H., 2000, Minor Prophets Part 2, Eerdmans, Grand Rapids, MI. (Forms of Old Testament Literature, 22)
Flusser, D., 2009, Judaism of the Second Temple Period, Volume 2: The Jewish sages and their literature, transl. A. Yadin, Eerdmans, Grand Rapids, MI.

García Martínez, F., 2007, Qumranica Minora I: Qumran origins and apocalypticism, edited by E.J.C. Tigchelaar, Brill, Leiden. (Studies on the Texts of the Desert of Judah, 63).

Gelston, A., 2010, תרי עשר The Twelve Minor Prophets, Deutsche Bibelgesellschaft, Stuttgart. (Biblia Hebraica Quinta, 13).

Grabbe, L.L., 2010, An introduction to Second Temple Judaism: History and religion of the Jews in the time of Nehemiah, the Maccabees, Hillel and Jesus, T\&T Clark, London.

Horgan, M.P., 2002, 'Habakkuk Pesher (1QpHab)', in J.H. Charlesworth (ed.), The Dead Sea Scrolls: Hebrew, Aramaic, and Geek texts with English translations. Volume
6B: Pesharim, other commentaries and related documents, pp. 157-185, Westminster John Knox, Louisville, KY. (The Princeton Theological Seminary Dead Wea Scrolls Project).

Instone Brewer, D., 1992, Techniques and assumptions in Jewish exegesis before 70 CE, J.C.B. Mohr, Tübingen. (Texte und Studien zum Antiken Judentum, 30).

Jagersma, H., 1985, A history of Israel from Alexander the Great to Bar Kochba, transl. J. Bowden, SCM, London.

Jokiranta, J., 2013, Social identity and sectarianism in the Qumran movement, Brill, Leiden. (Studies on the Texts of the Desert of Judah, 105).

Kaiser, W.C., 1992, Micah - Malachi, Word Books, Dallas, TX. (The Communicator's Commentary, 21)

Kaiser, W.C., 1998, A history of Israel: From the Bronze Age through the Jewish Wars, Broadman \& Holman, Nashville, TN.

Korpel, M.C.A., 2000, 'Introduction to the Series Pericope', in M.C.A. Korpel \& J.M. Oesch (eds.), Delimitation criticism. A new tool in biblical scholarship, pp. 1-50, Van Gorcum, Assen. (Pericope 1).

Lim, T.H., 2000, 'The Qumran Scrolls, multilingualism and biblical interpretation', in J.J. Collins \& R.A. Kugler (eds.), Religion in the Dead Sea Scrolls, pp. 57-73, Eerdmans, Grand Rapids, MI. (Studies in the Dead Sea Scrolls and Related Literature).

McCarter, P.K., 1986, Textual criticism: Recovering the text of the Hebrew Bible, Fortress, Philadelphia, PA. (Guides to Biblical Scholarship, OR Series, 11).

Murray, C.M., 2002, Wealth in the Dead Sea Scrolls and in the Qumran Community, Brill, Leiden. (Studies on the Texts of the Desert of Judah, 40).

Newsom, C.A., 2004, The self as symbolic space: Constructing identity and community at Qumran, Brill, Leiden. (Studies on the Texts of the Desert of Judah, 52).

Nowack, W., 1903, Die kleinen Propheten, Vandenhoeck \& Ruprecht, Göttingen. (Handkommentar zum Alten Testament, 3/4).

Oesch, J.M., 1979, Petucha und Setuma. Untersuchungen zu einer überlieferten Gliederung im hebräischen Text des Alten Testaments, Vandenhoeck \& Ruprecht, Göttingen. (ОВO 27.)

Perlitt, L., 2004, Die Propheten Nahum, Habakuk, Zephanja, Vandenhoeck \& Ruprecht, Göttingen. (Das Alte Testament Deutsch, 25/1)

Potgieter-Annandale, J., 1999, Qumran in and around the Bible: A new look at the Dead Sea Scrolls, Van Schaik, Pretoria.

Prinsloo, G.T.M., 1989, "n Literêr-eksegetiese analise van die boek Habakuk', unpublished DD-thesis, University of Pretoria, Pretoria.

Prinsloo, G.T.M., 1999, 'Reading Habakkuk as a literary unit: Exploring the possibilities', Old Testament Essays 12, 515-535.

Prinsloo, G.T.M., 2004, 'Habakkuk 1 - A dialogue? Ancient unit delimiters in dialogue with modern critical scholarship', Old Testament Essays 17, 621-645.

Prinsloo, G.T.M., 2009, 'Petuchot/Setumot and the structure of Habakkuk: Evaluating the evidence', in R. de Hoop, M.C.A. Korpel \& S. Porter (eds.), The impact of Unit Delimitation on exegesis, pp. 196-227, Brill, Leiden. (Pericope, 7)

Prinsloo, G.T.M., 2013a, 'From watchtower to holy temple: Reading the book of Habakkuk as a Spatial journey', in M.K. George (ed.), Constructions of Space IV: Habakkuk as a Spatial journey', in M.K. George (ed.), Constructions of Space IV: Burther developments in examining ancient Israel's social space, pp. 132-154,

Prinsloo, G.T.M., 2013b, 'Reading Habakkuk 3 in the light of ancient unit delimiters', HTS Teologiese Studies/Theological Studies 69(1), Art. \#1975, 1-11. http://dx.doi. org/10.4102/hts.v69i1.1975

Roberts, J.J.M., 1991, Nahum, Habakkuk, and Zephaniah: A Commentary, Westminster/John Knox, Louisville, KY. (Old Testament Library).

Rudolph, W., 1975, Micha - Nahum - Habakuk - Zephanja, Gerd Mohn, Gütersloh. (Kommentar zum Alten Testament, 13/3). 
Sanders, E.P., 2000, 'The Dead Sea sect and other Jews: Commonalities, overlaps and differences', in T.H. Lim (ed.), The Dead Sea Scrolls in their historical context, pp. 1-43, T\&T Clark, Edinburgh.

Sellin, E., 1930, Das Zwölfprophetenbuch, Werner Scholl, Leipzig. (Kommentar zum Alten Testament, 12)

Silberman, L.H., 1961, 'Unriddling the riddle: A study in the structure and language of the Habakkuk Pesher (1 Q p Hab)', Revue de Qumran 3, 323-364.

Slomovic, E., 1969-1971, 'Toward an understanding of exegesis in the Dead Sea Scrolls', Revue de Qumran 7, 3-15.

Talmon, S., 1987, 'Waiting for the Messiah: The spiritual universe of the Qumran covenanters', in J.N. Neusner et al. (eds.), Judaisms and their Messiahs at the turn of the Christian Era, pp. 111-137, Cambridge University Press, Cambridge.

Tov, E., 1992, Textual criticism of the Hebrew Bible, Fortress, Minneapolis, MN.

Tov, E., 2000, 'The background of the sense divisions in biblical texts', in M.C.A. Korpel \& J.M. Oesch (eds.), Delimitation criticism. A new tool in biblical scholarship, pp. 312-350, Van Gorcum, Assen. (Pericope 1).

Ulrich, E.C., 2000, 'The Qumran Biblical scrolls - The Scriptures of late Second Temple Judaism', in T.H. Lim (ed.), The Dead Sea Scrolls in their historical context, pp. 67-87, T\&T Clark, Edinburgh.
VanderKam, J.C., 2004, From Joshua to Caiaphas: High Priests after the Exile, Fortress Press, Minneapolis, MN.

VanderKam, J.C., 2011, 'The Wicked Priest revisited', in D.C. Harlow et al. (eds.), The "'other"' in Second Temple Judaism: Essays in honor of John J. Collins, pp. 350-1367, Eerdmans, Grand Rapids, MI.

Van der Woude, A.S., 1966, 'Der Gerechte wird durch seine Treue leben. Erwägungen zu Habakuk 2:4-5', in Studia Biblica et Semitica Theodoro Christiano Vriezen qui Munere Proffesoris Theologiae per XXV Annos Functus Est, ab Amicis, Collegis, Munere Proffesoris Theologiae per XXV Annos Functus
Discipulis Dedicata, pp. 367-375, Veenman, Wageningen.

Van der Woude, A.S., 1970, 'Habakuk 2 4', Zeitschrift für die Alttestamentliche Wissenschaft 82, 281-282.

Van der Woude, A.S., 1978, Habakuk - Zefanja, Callenbach, Nijkerk. (Prediking van het Oude Testament).

Van Katwijk, D.J., 1912, De prophetie van Habakuk, De Vries, Rotterdam.

Würthwein, E., 1973, Der Text des Alten Testaments: Eine Einführung in die Biblia Hebraica, 4. erweiterte Aufl., Württembergische Bibelanstalt, Stuttgart.

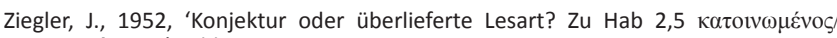

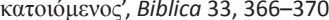




\section{Addendum 1: Textual witnesses utilised in the study Hebrew witnesses}

Proto-Masoretic ${ }^{48}$ manuscripts:

1. Pesher Habakkuk (1QpHab): One of the first scrolls discovered in Cave 1 at Qumran (Würthwein 1973:36). I consulted the photographs and transcription of the scroll by Burrows et al. (1950) and Cross et al. (1970) and the critical edition by Horgan (2002).

Burrows, M., J. C. Trever and W. H. Brownlee (eds.), 1950, The Dead Sea Scrolls of St. Mark's Monastery Volume 1: The Isaiah Manuscript and the Habakkuk Commentary, American Schools of Oriental Research, New Haven.

Cross, F. M., D. N. Freedman, and J. A. Sanders (eds.), 1970, Scrolls from Qumrân Cave I. The Great Isaiah Scroll; The Order of the Community; The Pesher to Habakkuk. From Photographs by John C. Trever, Albright Institute of Archaeological Research, Jerusalem.

Horgan, M. P., 2002, "Habakkuk Pesher (1QpHab)," in The Dead Sea Scrolls: Hebrew, Aramaic, and Geek Texts with English Translations. Volume 6B: Pesharim, Other Commentaries and Related Documents (ed. J. H. Charlesworth; PTSDSSP), Westminster John Knox, Louisville, 157-85.

2. Murabba'ât Twelve Prophets Scroll (MurXII): Dating from circa $130 \mathrm{CE}$, this badly damaged scroll contains a version of the Hebrew Twelve Prophets close to MT (Würthwein 1973:150).

Benoit, P., J. T. Milik, and R. De Vaux, (eds.) 1961, Les Grottes de Murabba'ât, Clarendon, Oxford. (DJD II). Published in two volumes, I: Texte (cf. pp. 181-205) and II: Planches (cf. Planche LXVIII-LXVIX).

Tiberian manuscripts of the Ben Asher tradition (Tov 1992:46-47):

3. Codex Cairo $\left(\mathrm{M}^{\mathrm{c}}\right)$ : According to the colophon it was copied and punctuated by Moshe ben Asher in $895 \mathrm{CE}$. It contains the Former and Latter Prophets (Würthwein 1973:38-39; Barthélemy 2012:240).

Codex Cairo of the Bible: From the Karaite Synagogue at Abbasiya: The earliest extant Hebrew manuscript written in 895 by Moshe ben Asher (Introduction by D.S. Lowinger), 1976, Makor, Jerusalem.

4. Codex Aleppo $\left(\mathrm{M}^{\mathrm{A}}\right)$ : According to the colophon it was copied in $925 \mathrm{CE}$. It is regarded as the model example of a Ben Asher manuscript (Würthwein 1973:39; Barthélemy 2012:239-240).

Aleppo Codex: Provided with massoretic notes and pointed by Aaron Ben Asher, 1976, Makor, Jerusalem. (The Hebrew University Bible Project).

5. Codex Leningrad $\left(\mathrm{M}^{\mathrm{L}}\right)$ : It is the oldest complete Ben Asher manuscript of the Hebrew Bible, copied in 1008-1009 CE (Würtwein 1973:39; Barthélemy 2012:239).

Pentateuch, Prophets and Hagiographa: Codex Leningrad $B$ 19A, 1970, Makor, Jerusalem.

48.Following Tov (1992:19) I define 'proto-Masoretic' as earlier forms of the Hebrew Bible consonantal text 'lacking the later vocalization and accentuation'.
Manuscripts with non-Tiberian vocalisation:

6. Codex Petropolitanus $\left(\mathrm{M}^{\mathrm{P}}\right)$ : According to the colophon the manuscript was copied in $916 \mathrm{CE}$. It utilises Babylonian vowel signs, but in the consonantal text and punctuation it follows the Tiberian tradition (Würthwein 1973:40; Barthélemy 2012:238).

The Hebrew Bible - Latter Prophets: The Babylonian Codex of Petrograd edited with preface and critical annotations by Hermann L. Strack. Prolegomenon by P. Wernberg-Møller, 1971, Ktav, New York.

7. Codex Reuchlinianus $\left(\mathrm{M}^{\mathrm{R}}\right)$ : The manuscript contains the former and latter prophets and dates from circa 1105 CE. The vocalisation of the manuscript is proto-Tiberian and it contains both the Masoretic text and the Targum Jonathan to the Prophets.

Codex Reuchlinianus. No. 3 of the Badische Landsbibliothek in Karlsruhe (Formerly Durlach No. 55) with a general introduction: Masoretic Hebrew by Alexander Sperber, 1956, Munksgaard, Copenhagen. (The Pre-Masoretic Bible, I).

Printed editions of the Hebrew Bible:

8. Biblia Rabbinica (BibRab): The so-called Second Rabbinic Bible was prepared by Jakob ben Chayyim and printed by Daniel Bomberg in Venice in 1524-1525. The Hebrew text occurs together with the Aramaic translation and the Rabbinic commentaries of Rashi, Ibn Ezra and Kimchi (Würthwein 1973:42; Deist 1978:84).

Biblia Rabbinica: A reprint of the 1525 Venice edition edited by Jacob ben Hayim ibn Adoniya, 1972, Makor, Jerusalem.

9. Biblia Hebraica Stuttgartensia (BHS): A 'critical' edition of the Hebrew Bible based upon $\mathrm{M}^{\mathrm{L}}$, prepared under the auspices of the Deutsche Bibelgesellchaft (Deist 1978:86).

Elliger, K. \& Rudolph, W., 1967/77, Biblia Hebraica Stuttgartensia, Deutsche Bibelgesellschaft, Stuttgart.

10. Biblia Hebraica Quinta (BHS): A revised 'critical' edition of the Hebrew Bible based upon $M^{L}$, currently prepared under the auspices of the Deutsche Bibelgesellchaft.

Gelston, A., 2010, תרי עשר The Twelve Minor Prophets, Deutsche Bibelgesellschaft, Stuttgart. (Biblia Hebraica Quinta, 13).

\section{Aramaic witnesses}

Manuscript with non-Tiberian vocalisation:

1. Codex Reuchlinianus ( $\left.\mathrm{M}^{\mathrm{R}}\right)$ : Cf. Hebrew witnesses (7). The manuscript contains both the Hebrew and Aramaic text of the Former and Latter Prophets.

Printed editions of the Targum:

2. Printed version of the Aramaic text of Codex Reuchlinianus edited by De Lagarde (1967).

De Lagarde, P. (ed.), 1967, Prophetae Chaldaice e fide codocos reuchliani, Otto Zeller, Osnabrück.

3. The Targum Jonathan edited by Sperber (1962). Sperber, A. (ed.), 1962, The Bible in Aramaic based on old manuscripts and printed texts Volume III: The Latter Prophets according to Targum Jonathan, Brill, Leiden. 


\section{Greek witnesses}

Scroll from the Judean Desert:

1. Greek Minor Prophets scroll from Nahal Hever (8HevXIIgr): Dates from between 50 BCE and 50 CE and contains a Greek translation of the Twelve Minor Prophets. It shows similarities with Aquila, Symmachus and Theodotion and represents a recension of the Septuagint containing a literal translation of an apparently pre-Masoretic Hebrew text (Würthwein 1973:178; Barthélemy 2012:443-444).

Tov, E. The Greek Minor Prophets scroll from Nahal Hever (8HevXIIgr) (The Seiâl Collection 1) (DJD VIII), Oxford 1990.

Uncial Septuagint manuscripts:

2. Codex Sinaiticus $\left(G^{S}\right)$ : Dates from the fourth century CE. Originally contained the entire Bible, but large parts of the Old Testament have been lost (Deist 1978:190).

Codex Sinaiticus Petropolitanus et Friderico-Augustanus Lipsiensis: The Old Testament preserved in the public library of Petrograd, in the library of the Society of Ancient Literature in Petrograd, and in the library of the University of Leipzig now produced in facsimile from photographs by Helen and Kirsopp Lake, 1922, Clarendon, Oxford.

3. Codex Vaticanus $\left(\mathrm{G}^{\mathrm{B}}\right)$ : Dates from the fourth century $\mathrm{CE}$ and contains the entire Bible. It is regarded as the best complete Septuagint manuscript (Deist 1978:190).

Bibliorum Sacrorum Graecus Codex Vaticanus Tomus IV: Libros Esther, ludith, Tobiae et Prophetarum, 1872, Congregationis de Propaganda Fide, Roma.

4. Codex Alexandrinus $\left(\mathrm{G}^{\mathrm{A}}\right)$ : Dates from the fifth century $C E$ and contains the entire Bible (Deist 1978:191).

Codex Alexandrinus, 1936, The Codex Alexandrinus in reduced photographic facsimile: Old Testament, Part III Hosea-Judith, (ed. F.G. Kenyon), 1936, British Museum, London.
5. Codex Marchalianus $\left(\mathrm{G}^{\mathrm{M}}\right)$ : Dates from the sixth century CE and contains the prophetic books. It is of interest because hexaplaric notes occur in the margins (Deist 1978:191).

Prophetarum Codex Graecus Vaticanus 2125 Qui Dicitur Marchalianus, (ed. J. Cozza-Luzi), 1890, Bibliotheca Vaticana, Romae.

\section{Syriac witnesses}

1. Codex Ambrosianus (7a1): Dates from the sixth to seventh century CE and contains the entire Old Testament written in elegant Estrangela script (Deist 1978:147-148).

Ceriani, A.M., 1876-1883, Translatio syra pescitto Veteris Testamentiex Codice Ambrosiano sec. fere VI photolithographice editacuranteetadnotanteMediolani:Inofficinis photolithographica Angeli della Croce et typographica J.B. Pogliani et sociorum, Williams \& Norgate, London. Available online: https://archive. org/details/CerianiVeterisTestamentum7a1PeshittaTanakhAra maicOldTestament, accessed 2015/09/29

2. Peshitta: Printed version of the Syriac Old Testament with the Codex Ambrosianus as base text, produced by the Peshitta Institute in Leiden.

Old Testament in Syriac According to the Peshitta Version. Edited on Behalf of the International Organization for the Study of the Old Testament by the Peshitta Institute Leiden. Part III, Fascicle 4. Dodekapropheton-Daniel-Bel-Draco, 1980, Brill, Leiden.

\section{Latin witness}

1. Vulgate: I utilised the critical printed edition prepared by the Benedictine order published since 1926 in numerous volumes (Deist 1978:213).

Biblia Sacra iuxta Latinam Vulgatam Versionem XVII: Duedecim Prophetarum, 1987, Libreria Editrice Vaticana, Roma.

Appendix contined next paga $\rightarrow$ 


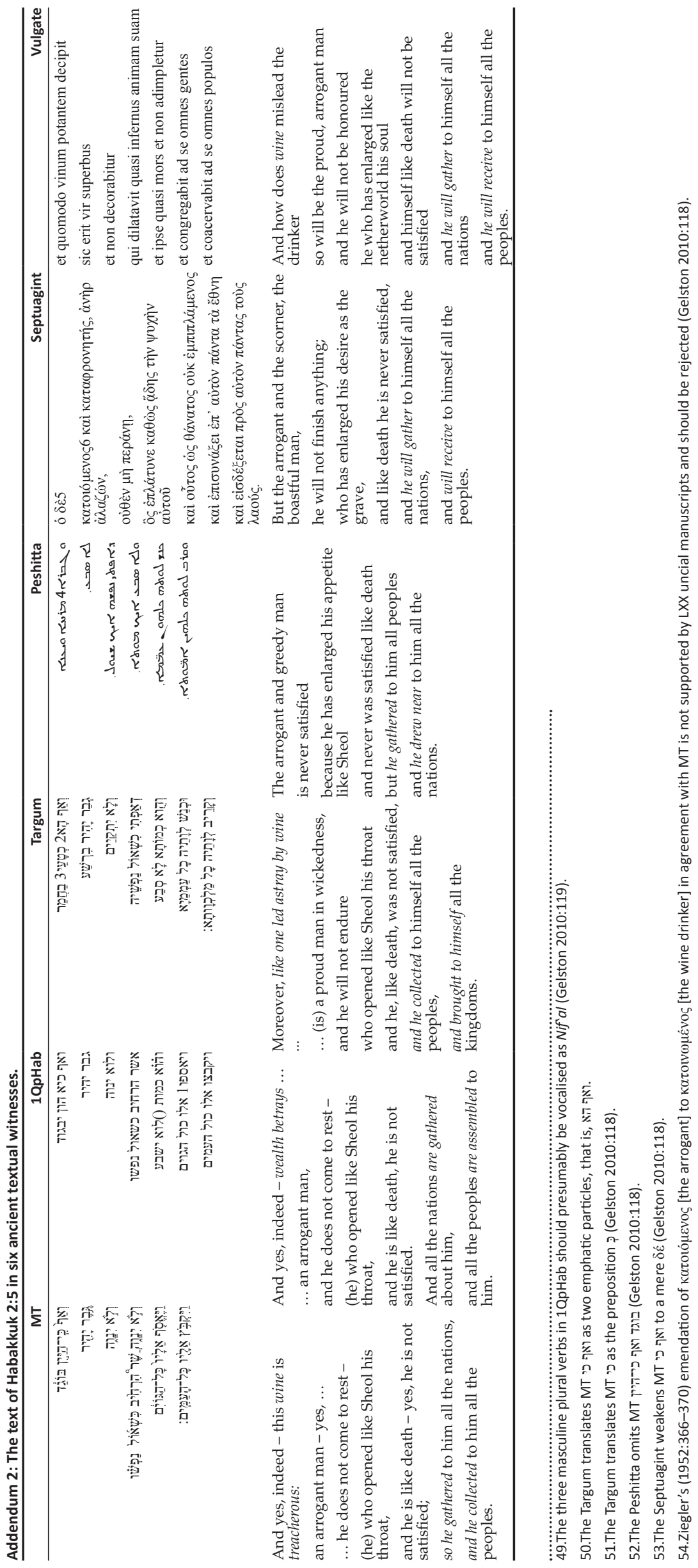

